\title{
LIFE WITH OXIDATIVE STRESS
}

\author{
Dorota Gurda $^{1}$, Anna M. Kietrys ${ }^{1}$, Aleksandra Szopa ${ }^{2}$, Tomasz Twardowski ${ }^{* 1}$ \\ ${ }^{1}$ Institute of Bioorganic Chemistry, Polish Academy of Sciences, Z. Noskowskiego St.12/14, \\ Poznań, Poland \\ ${ }^{2}$ Institute of Technical Biochemistry, Technical University of Łódź, B. Stefanowskiego St. 4/10, \\ Łódź, Poland
}

\begin{abstract}
Incomplete oxygen reduction gives rise to reactive oxygen species (ROS). For a long time they have been considered unwelcome companions of aerobic metabolism. Organisms using oxygen developed several systems of ROS scavenging with enzymatic and non enzymatic antioxidants, which allow them control the cellular level of oxygen derived from free radicals. It is well established nowadays that ROS are not necessarily negative byproducts, but they also play an important role in cellular mechanisms. They are involved in many regular cellular processes in all aerobic organisms. When the antioxidant system is overcome and the balance between ROS production and scavenging is disrupted, oxidative stress occurs. It has been reported that oxidative stress may be linked to some human diseases and is also involved in biotic and abiotic stress response in plants.
\end{abstract}

Keywords: ROS, oxidative stress, antioxidants, oxidative stress response

\section{INTRODUCTION}

My first meeting with Professor Krzysztof Szewczyk concerned (of course!) biotechnology but not the science. We talked about activities of Polish Federation of Biotechnology and... both of us concluded how much energy we needed for the Federation. Professor Krzysztof Szewczyk was the vice-president of the Federation and he invested a lot of energy and put a lot of his enthusiasm in the establishment of modern biotech in our country. Right then this conversation was very close to the problem of... ecological and sustainable resources of energy, bioenergy and sustainable development. Both of us (basic scientists with a training in chemistry) were enthusiastic about the potential and progress of modern biotechnology. Several different aspects of energy production: using bacteria, plants as well as waste, have been always in the centre of Professor Krzysztof Szewczyk's interests. So, the basic research carried out with my scientific team dedicated to the oxidative stress in plant system was of interest to him, as well.

It was a great privilege to meet and cooperate with Professor Krzysztof Szewczyk. His youthful enthusiasm concerning any form of intellectual activity and optimism were extremely helpful in many fields. I was saddened to learn of Professor Krzysztof Szewczyk passing away on October 20, 2011. I miss him very much. 


\section{LIVING WITH OXYGEN}

\subsection{ROS chemistry and oxidative stress}

The environment of most organisms is rarely constant as internal or external stimuli continually disrupt homeostasis inducing stress. Organism responses to stresses are equally complex (Avery, 2011). About $\sim 2.7$ billion years ago molecular oxygen was introduced in the Earth's atmosphere by the $\mathrm{O}_{2}$-evoluting photosynthetic organisms (Halliwell, 1981). Oxygen is now the most prevalent element in Earth's environment (Magder, 2006). Reactive oxygen species (ROS) proved to be unwelcome companions of aerobic life (Gill and Tuteja, 2010; Halliwell, 2006). Ground state triplet molecular oxygen is a radical with its two outermost valence electrons occupying separate orbitals with parallel spins (Cadenas, 1989). The $\mathrm{O}_{2}$ molecule is a free radical, as it has two impaired electrons that have the same spin quantum number. The spin restriction makes $\mathrm{O}_{2}$ prefer to accept its electrons one at a time, leading to a generation of the so-called ROS. In an "oxidative stress" concept ROS appear as unavoidable toxic products of $\mathrm{O}_{2}$ metabolism and aerobic organisms have evolved mechanisms of antioxidant protection (Halliwell, 1981). Many years of studies have indicated reactive oxygen species as markers of oxidative stress and signalling events, which are responsible for induction of adaptive stress response (Mittler et al., 2004; Pucciariello et al., 2012).

In eukaryotic organisms ROS are continuously produced as byproducts of many metabolic pathways localised in different cellular compartments (Apel and Hirt, 2004). Moreover, ROS are produced in response to certain environmental changes by activating various oxidases and peroxidases (Allan and Fluhr, 1997). Under physiological steady state conditions ROS are scavenged by components of antioxidative defence (Donahue et al., 1997). The equilibrium between production and scavenging of reactive oxygen species may be perturbed by environmental factors which results in a rapid increase of ROS level. This situation leads to oxidative stress (Feild et al., 1998; Sies, 1991). It is established that organelles (mitochondria, peroxisomes and chloroplasts) with a highly oxidising metabolic activity or with an intense rate of electron flow are the major source of ROS in cells. It has been estimated that $1-2 \%$ of $\mathrm{O}_{2}$ consumed by plants is sidetracked to produce $\mathrm{ROS}$ and $1-3 \%$ of $\mathrm{O}_{2}$ reduced in mitochondria is found in the form of $\mathrm{O}_{2}{ }^{-}$(Temple et al., 2005; Turrens, 2003). A single electron reduction of $\mathrm{O}_{2}$ results in the generation of $\mathrm{O}_{2}{ }^{-}$with approximately 2-4 $\mu$ s of half-life. It has been established that in plants ROS appear during photosynthesis in chloroplasts by partial reduction of $\mathrm{O}_{2}$ or energy transfer to them. $\mathrm{O}_{2}{ }^{--}$is produced upon reduction of $\mathrm{O}_{2}$ during electron transport along the non-cyclic pathway in the electron transport chain (ETC) of chloroplasts and other compartments, this process can occur at the level of photosystem I (PSI) (Halliwell, 2006; Puntarulo et al., 1988). At low $\mathrm{pH}$ conditions, dismutation of $\mathrm{O}_{2}{ }^{-}$is unavoidable, with one $\mathrm{O}_{2}{ }^{-}$giving up its added electron to another $\mathrm{O}_{2}{ }^{--}$, and then with protonation resulting in the generation of $\mathrm{H}_{2} \mathrm{O}_{2} \cdot \mathrm{O}_{2}{ }^{-}$can be also protonated to form the $\mathrm{HO}_{2}{ }^{\circ} \mathrm{O}_{2}{ }^{\circ}$ in the presence of metals such as $\mathrm{Cu}, \mathrm{Fe}$ undergoes further reactions and gives up $\mathrm{OH}^{\circ}$. $\mathrm{O}_{2}{ }^{--}$donates an electron to iron $\left(\mathrm{Fe}^{3+}\right)$ to yield a reduced form of iron $\left(\mathrm{Fe}^{2+}\right)$ which can then reduce $\mathrm{H}_{2} \mathrm{O}_{2}$, produced as a result of superoxide dismutase (SOD) led dismutation of $\mathrm{O}_{2}{ }^{--}$to $\mathrm{OH}^{*} . \mathrm{OH}^{*}$ is the most reactive form of ROS. The first step of a reaction through which $\mathrm{O}_{2}{ }^{-}, \mathrm{H}_{2} \mathrm{O}_{2}$ and iron generate $\mathrm{OH}^{*}$ is called the Haber-Weiss reaction. The final step reaction which involves the oxidation of $\mathrm{Fe}^{2+}$ by $\mathrm{H}_{2} \mathrm{O}_{2}$ is called the Fenton reaction (Halliwell, 2006; Scarpeci et al., 2008). $\mathrm{H}_{2} \mathrm{O}_{2}$ is restrainedly reactive and has a long half-life of $1 \mathrm{~ms}$ (Gill and Tuteja, 2010). In mammals $\mathrm{O}_{2}{ }^{--}$comes from complex NADH dehydrogenase and complex II (ubiquinone-cytochrome $\mathrm{c}$ reductase). It was also showed that in stress conditions the active site of xanthine oxidase (XOD), which normally acts as a dehydrogenase, is oxidised and the enzyme acts as an oxidase and produces $\mathrm{O}_{2}{ }^{-} \cdot \mathrm{O}_{2}{ }^{-}$can be also produced by cytochrome P450 enzymes as a side reaction when they break down target molecules (Magder, 2006). The ${ }^{1} \mathrm{O}_{2}$ form occurs when an electron is elevated to a higher energy orbital, thereby freeing oxygen that forms its spin-restricted state. ${ }^{1} \mathrm{O}_{2}$ can also be formed through photoexcitation of chlorophyll and its reaction with $\mathrm{O}_{2}$. Insufficient energy dissipation during photosynthesis can lead to the formation of chlorophyll 
triple state which can react with ${ }^{3} \mathrm{O}_{2}$ to give up ${ }^{1} \mathrm{O}_{2}$. The life time of ${ }^{1} \mathrm{O}_{2}$ is approximately $3 \mu$ s and it is continuously produced by PSII. It has been noted that in plants some species constitutively produce different types of secondary metabolite with photosensitising properties that use ${ }^{1} \mathrm{O}_{2}$ to increase efficacy as antimicrobial agents (Flors and Nonell, 2006; Gill and Tuteja, 2010).

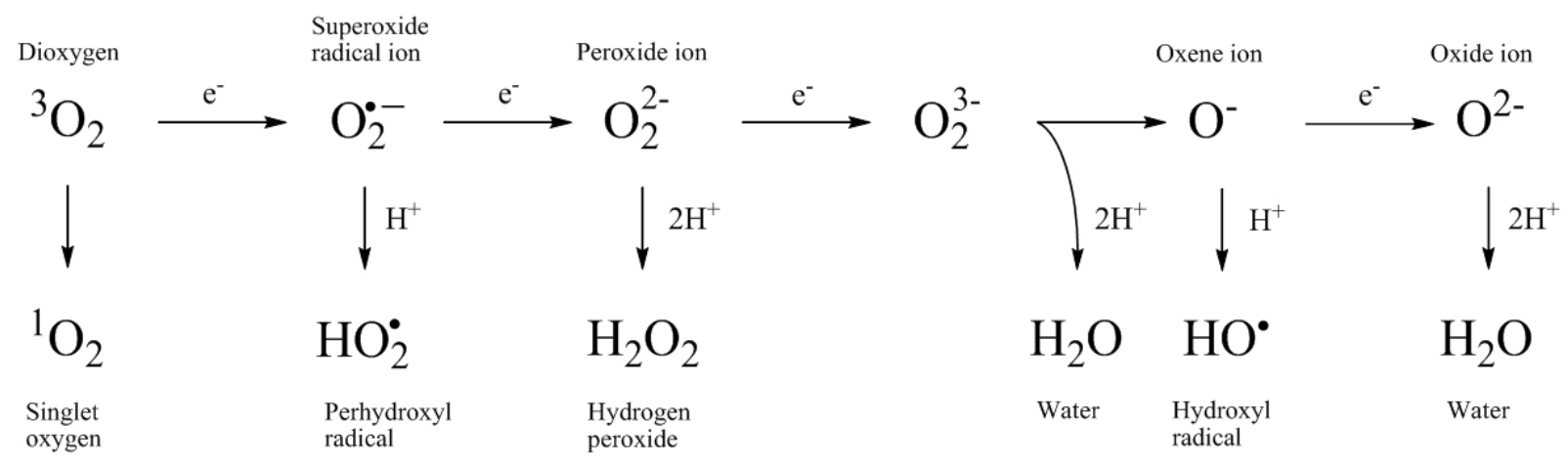

Fig. 1. Scheme of generation of ROS in cell (Apel and Hirt, 2004)

A significant fact is that ROS are produced as part of normal metabolism (Fones and Preston, 2012). It is noted that ROS are important chemical mediators that regulate the transduction of signals by modulating protein via redox chemistry (Kovacic and Pozos, 2006). It has been proposed that ROS have been conserved throughout evolution as universal second messengers (Schulze-Osthoff et al., 1997). It is well known that ROS also play a crucial role in various pathophysiological processes such as cancer, neurodegenerative disorders, autoimmune disease and in plants in oxidative stress defence or oxidation and damaging of macromolecules (Apel and Hirt, 2004; Takahashi et al., 2011). ROS are strong oxidising agents and can cause lipid peroxidation, protein oxidation and damage of nucleic acids (Fones and Preston, 2012). The function of biological membranes is to constitute selectively impermeable barriers and partake in cellular transport processes. The presence of transition metals and ROS forms such as superoxide anion and hydroxyl radical initiates lipid peroxidation. A single initiation event has the potential to generate multiple peroxide molecules by chain reaction (Evans and Halliwell, 1999; Halliwell, 1999). The effects of lipid peroxidation reaction are decreased membrane fluidity, increase of the leakiness of the membrane to substances that do not normally cross it, damage of membrane proteins and inactivation of receptors, ion channels and enzymes (Moller et al., 2007). It was observed that ROS such as $\mathrm{OH}^{*}$ and ${ }^{1} \mathrm{O}_{2}$ take part in oxidative damage of nucleic acids. RNA damage has not received much attention, because damaged molecules do not accumulate in cell. However, cellular RNA is likely to be more prone to oxidative damage than DNA. RNA damage by ROS results in either the loss or alteration of RNA functions. It has been noted that oxidative lesions alter the structure of RNA or interfere with the interaction between RNA and other cellular molecules ( $\mathrm{Li}$ et al., 2006). It was shown that ROS can initiate the formation of more than 20 types of oxidative DNA damage the most prevalent of which is the 8-oxoguanine (Avery, 2011). The hydroxyl radical is the most reactive form and causes damage to all components of the DNA molecule (Wiseman and Halliwell, 1996). ROS induce DNA damage which includes base deletion, pyrimidine dimers, crosslinks, strands breaks and bases modification, such as alkylation and oxidation. All these forms of oxidative damage result in various physiological effects, such as protein synthesis reduction, membrane destruction, whose affects disrupt the growth and development of organisms (Britt, 1999; Tuteja et al., 2001). Protein oxidation results in cellular dysfunction and has a negative impact on cellular metabolism (Cecarini et al., 2007). This process is defined as covalent modification of a protein induced by free radicals or byproducts of oxidative stress. Most types of protein oxidative modifications are irreversible, but a few involving sulfur-contaning amino acids are reversible (Ghezzi and Bonetto, 2003). The oxidation of a number of protein amino acids gives rise to free carbonyl groups which can alter or inhibit their activities and increase susceptibility towards proteolytic attack (Moller et al., 2007). An important aspect of ROS toxicity is the localisation in the cell of toxic reaction 
triggered by oxidative modification of a cellular target. Several potential targets may manifest toxic character during oxidative stress (Avery, 2011).

ROS signalling is thought to be perturbed by different developmental or environmental signals which can up- or down-regulate their level. Moreover, ROS signalling and its level is controlled by two opposing processes of production and scavenging (Mittler et al., 2004). Scavenging cells from free radicals are formed following non-enzymatic or enzymatic reactions. Superoxide dismutase is the most effective enzymatic antioxidant in all aerobic organisms and all subcellular compartments. SOD removes $\mathrm{O}_{2}{ }^{-}$by catalysing its dismutation, which can be reduced to $\mathrm{H}_{2} \mathrm{O}_{2}$ or oxidised to $\mathrm{O}_{2}$. The enzyme removes $\mathrm{O}_{2}{ }^{-}$and decreases the risk of $\mathrm{OH}^{-}$formation (Mittler, 2002). Catalase (CAT) dismutates $\mathrm{H}_{2} \mathrm{O}_{2}$ into $\mathrm{O}_{2}$ and $\mathrm{H}_{2} \mathrm{O}$. CAT is particularly important in the removal of $\mathrm{H}_{2} \mathrm{O}_{2}$ in peroxisomes (Gill and Tuteja, 2010). Ascorbate peroxidase (APX) plays a crucial role in scavenging free radicals of $\mathrm{H}_{2} \mathrm{O}_{2}$ in water-water and ASH-GSH cycle, since it utilises ASH as the electron donor (Badawi et al., 2004). Glutathione reductase (GR) is a flavoprotein oxidoreductase and it plays a role in defence against ROS by sustaining the reduced status of GSH. This enzyme has been localised in chloroplasts and in small amounts in mitochondria and cytosol (Romero-Puertas et al., 2006). Monodehydroascorbate reductase (MDHAR) is an enzyme present in chloroplasts and cytosol, it has high specificity for monodehydroascorbate (MDHA) as an electron acceptor, preferring NADH as an electron donor (Asada, 1999). Dehydroascorbate reductase (DHAR) is connected with ASH regeneration from oxidised state and regulation of the cellular ASH redox state (Gill and Tuteja, 2010). Glutathione S-transferase (GST) is an enzyme which catalyses the conjugation of electrophilic xenobiotic substrates with tripeptide glutathione (Roxas et al., 2000). Glutathione peroxidases (GPX) comprise a large group of isozymes. GPXs use GSH to reduce $\mathrm{H}_{2} \mathrm{O}_{2}$ and lipid and organic hydroperoxides in ROS scavenging process (Noctor et al., 2002). The antioxidant defence system also includes non-enzymatic antioxidants such as vitamins $\mathrm{C}$ and $\mathrm{E}$, glutathione, Proline, flavonoids and carotenoids (Gill and Tuteja, 2010). Ascorbic acid - vitamin C is the most important water soluble antioxidant. Vitamin $\mathrm{C}$ has the ability to donate electrons in a number of reactions. It can scavenge $\mathrm{O}_{2}{ }^{-}$ and $\mathrm{OH}^{*}$ and regenerate $\alpha$-tocopherol from tocopheroxyl radical (Smirnoff, 2000). $\alpha$-tocopherol (vitamin E) is a lipid soluble antioxidant that takes part in the removal of some ROS such as ${ }^{1} \mathrm{O}_{2}$ and lipid radicals (Kamal-Eldin and Appelqvist, 1996). Glutathione (GSH) is a scavenger of ${ }^{1} \mathrm{O}_{2}, \mathrm{H}_{2} \mathrm{O}_{2}$ and $\mathrm{OH}$ and it is considered to be the most important intracellular antioxidant (Mullineaux and Rausch, 2005). Proline was proposed as an osmoprotectant, a protein stabiliser, a metal chelator, an inhibitor of lipid peroxidation and as ${ }^{1} \mathrm{O}_{2}$, and $\mathrm{OH}^{\cdot}$ remover (Verbruggen and Hermans, 2008). Flavonoids scavenge ROS by locating and neutralising damage in the cell, and their antioxidative activity consists in the reduction of radicals. Carotenoids similarly react with peroxyl radicals to form a resonance-stabilised carbon-centred radical within its conjugated alkyl structure, thereby inhibiting chain propagation of reactive oxygen species (Fang et al., 2002). To sum up, the cell defence against ROS and oxidative stress depends on enzymatic and non-enzymatic antioxidants acting to decrease ROS concentrations, repair damaged molecules and eliminate irreparable proteins (Sigler et al., 1999).

The oxidative stress caused by ROS is ubiquitous in all organisms. It is a subject of extensive research, particularly in humans and plants, as it is involved in some human diseases and plant stress responses. In this review we focus on those two fields of research.

\subsection{Oxidative stress in humans}

Overproduction of reactive oxygen species evoking oxidative stress can damage the most important cellular molecules such as nucleic acids, proteins and lipids, resulting in serious diseases and dysfunction of living organisms. 
High concentration of ROS in blood vessel results in many pathological consequences. It is well known, that the inflammatory state mediated by ROS causes damage of endothelial and smooth muscle cells. Endothelial dysfunction is represented by disrupting anti-inflammatory, anticoagulant, and vasorelaxation properties as well as activation of monocytes, macrophages, growth factors which leads to the formation of atherosclerotic plaque. It is formed from low density lipoproteins oxidised by free radicals (oxLDL) (Seifried et al., 2007). After oxidation LDL particles are recognised by scavenger receptors on immune system cells (monocytes and macrophages), which subsequently bind to modified LDL. There are eight classes of such receptors, but only SR-A type I and II, CD 36 and LOX1 are able to uptake oxLDL (de Beer et al., 2003), evolving to lipid filled foam cells. LOX1 is thought to be the main receptor for oxLDL expressed on the surface of endothelial cells which are the most susceptible to negative changes during atheroma formation. Foam cells, unable to process oxidised cholesterol, enlarge until rupture resulting in a great amount of cholesterol deposition on the artery wall. As a result of deposition the artery wall becomes inflamed. Various inflammatory cytokines and growth factors released by macrophages cause smooth muscle cells and fibroblast proliferation and thrombus formation (Goyal et al., 2012; Kong and Lin, 2010). ROS-mediated oxidative stress also plays a crucial role in the progression of atherosclerosis. There are studies indicating that nucleic acid undergoes oxidation during the sclerotic plaque formation. Increased levels of oxidative damage in human sclerotic plaque were shown to result in higher amounts of 8-hydroxy-2-deoxyguanosine (8-OHdG), the most frequent oxidative change in mammalian DNA (Martinet et al., 2002). It was also reported that RNA is also prone to oxidative damage in smooth muscle cells and endothelial cells in human atherosclerotic lesions (Martinet et al., 2004, 2005).

Brain tissue is extremely sensitive to oxidative degradation, because of its very large demand for oxygen, high polyunsaturated fatty acids and redox-active metals $(\mathrm{Cu}, \mathrm{Fe})$ presence. Oxidative stress increases with age and may lead to very serious oxidative injuries that may trigger many neurodegenerative disorders. One of the major neurodegenerative disorders is Alzheimer's Disease (AD). Oxidative stress is considered to be one of the major factors related to AD pathogenesis as well as dysregulation of amyloid beta precursor protein (APP) functioning and amyloid beta peptide (A $\beta$ ) metabolism. AD leads to accumulation of $A \beta$ and neurofibrially tangels. $A \beta$ can be oxidised by metalcalatysed hydroxyl radicals and become more water-insoluble and resistant to protease (Atwood et al., 2004). It is worth mentioning that genes coding $A \beta$ and enzyme beta amyloid precursor protein (BACE) expression is regulated through methylation of its promoter regions. On the basis of experiments on oxidant-transformed cell lines it is suggested that DNA methylation process and DNA oxidative damage interact together, which can alter methylation patterns resulting in transcriptional regulation of gene expression. This way oxidative and methylation changes in the promoter region of APP gene may regulate production of the protein encoded by this gene and its derivatives (Chan and Shea, 2006). The APP promoter sequence consists of $72 \% \mathrm{CpG}$ islands. A sequence analysis of this revealed at least 13 possible methylation sites. There were $26 \%$ of methylated cytosines in the brain tissues from healthy individuals between 36 to 70 years compared to $8 \%$ of cytosine methylation in a group AD subjects aged 74 to 90 . According to some authors this significant decrease of methylation level related to age may be significant in the $A \beta$ aggregation in brain (Zawia et al., 2009). The second most common neurodegenerative disorder is Parkinson's Disease (PD). Etiology of this illness is manifested in a loss of dopaminergic neurons in the substantia nigra and in the presence of neuronal inclusions of $\alpha$-synuclein, called Lewy bodies. Oxidative stress is proposed to be one of the crucial pathogenic factors. Dopamine is a good metal chelator and donor of electrons and is able to react with iron and manganese. Many studies indicate that mutations in $\alpha$-synuclein gene may result in facilitating dopamine reaction with iron increasing ROS production. Manganese is capable of causing oxidative DNA damage and reducing antioxidants such as GSH, catalase and thiols (Kong and Lin, 2010).

Oxidative damage of nucleic acids is also considered to be a factor underlying pathophysiology of neurodegenerative diseases. Among many products of nucleoside oxidation only two, 8-hydroxy-2-deoxyguanosine $(8 \mathrm{OHdG})$ and 8-hydroxyguanosine $(8 \mathrm{OHG})$, are well characterised. 
In two most frequent neurodegenerative disorders, $\mathrm{AD}$ and $\mathrm{PD}$, elevated levels of $8 \mathrm{OHG}$ and $8 \mathrm{OHdG}$ were found. Their strong abundance in cytoplasm and neurons, suggests that mitochondrial DNA and cytoplasmic RNA in neurons are most prone to oxidative stress (Alam et al., 1997; Nunomura et al., 1999). Similar oxidation of neuronal cytoplasmic RNA was observed in brain samples of patients with other disorders such as Creutzfeldt-Jacob Disease, Down's Syndrome (Nunomura et al., 2009). Elevated RNA oxidation was also observed in substantia nigra in patients with PD, indicating that those changes may occur in the early stage of this illness (Kong and Lin, 2010).

It was demonstrated that up to $50 \%$ of mRNA isolated from brains of patients with mild or moderate stage of AD is oxidatively damaged (Shan and Lin, 2006). An analysis of oxidative changes in mRNA revealed that those changes are not random. Some types of polyA $(+)$ mRNA are more vulnerable to oxidative damage than others. For example, mRNA for copper/zinc superoxide dismutase (SOD1) and dynactin 1 is highly oxidised in amyotrophic lateral sclerosis, resulting in a decreased level of proteins encoded by them (Chang et al., 2008). A similar observation was made in post mortem analysis of brains from patients with AD. Some of the mRNA with elevated oxidation encoded for example p21 ras or mitogen-activated protein kinase (MAPK), SOD1, but not for amyloid $\beta$ precursor or tau protein (Shan et al., 2003).

Impaired redox state is a feature of many cancer cells. The oxidative DNA damage has been implicated in the etiology of cancer. There are over 100 different products of oxidative nucleic acid damage. These are single or double stranded DNA breaks, purine and thymidine or deoxyribose modifications and DNA cross-links. The oxidative stress plays a role in any stage of carcinogenesis and apoptosis (Valko et al., 2007). For example, oxidation of guanosine resulting in the creation of highly mutagenic particle, $8 \mathrm{OHdG}$, which leads to $\mathrm{G}: \mathrm{C}$ to $\mathrm{T}: \mathrm{A}$ transversion, a characteristic feature of oncogenes and tumour suppressor genes (Seifried et al., 2007). There are many observations revealing that oxidative damage of mitochondrial DNA is also involved in carcinogenesis. Mutations and altered expression in mitochondrial genes encoding complexes I, III, IV and V in hipervariable regions have been connected to many human cancers. ROS are implicated in the activation of the nuclear genes involved in mitochondrial biogenesis, transcription and replication of mitochondrial genome (Valko et al 2006). It was also found that fragments of mitochondrial DNA were inserted into nuclear DNA, suggesting its role in the activation of carcinogenesis. It has been also established that lipid peroxidation is also linked to carcinogenesis. Lipoperoxyl radical ( $\left.\mathrm{ROO}^{\circ}\right)$ is prone to cyclisation reaction resulting in the formation of malondialdehyde (MDA). It was observed that MDA is mutagenic in mammalian cells, bacterial, and rats. It can react with guanosine, adenosine and cytosine in DNA creating adducts $\mathrm{M}_{1} \mathrm{G}, \mathrm{M}_{1} \mathrm{~A}$, and $\mathrm{M}_{1} \mathrm{C}$. It was found that $\mathrm{M}_{1} \mathrm{G}$ is mutagenic in Escherichia coli, and may cause transversion to $\mathrm{T}$ or transitions to A (Valko et al., 2007; Valko et al., 2006).

ROS may impair cellular defence mechanisms protecting from carcinogenesis. There are two main mechanisms of carcinogenesis induction. In the first mechanism increased DNA synthesis and mitosis by nongenotoxic carcinogens may lead to mutation in dividing cells through misrepair. In the other mechanism cell divisions mutations may expand leading to serious changes in DNA sequence. The second theory assumes balance between cell death and proliferation. When DNA damage level is too high, cellular mechanisms are activated to specifically direct the cell to apoptosis pathway. During proliferation, the main protein controlling the integrity of cellular DNA is p53 protein. It recognises mutations and initiates repairing mechanisms. If there are too many mutations, the cell is directed to apoptosis. Any change in this specific process may result in carcinogenesis. p53 functions as a transcription factor activating or repressing expression of targeted genes involved in a cell cycle. p53 is very redox sensitive because of its structure. It consists of many cysteine residues that contain redox sensitive thiol groups. Oxidative modifications of this group result in disulfide bonds formation, that induces structural changes, which alter its affinity to sequence specific binding to targeted genes. This suppressor gene is the most mutated gene in human cancers. It was reported, that mutations in p53 may be caused by ROS or by carcinogenic metals. Some reports indicate that mutations in p53 by the 
exposition to $\mathrm{NO}^{\bullet}$ and its derivatives are connected to stomach, brain and breast cancer (Valko et al., 2007; Valko et al., 2006; Vurusaner et al., 2012). It is also known that oxidative stress plays a role in the development of hepatocellular carcinoma (HCC). NO may be involved in protection or in development of tumour depending on the environment. It was suggested that lower concentrations of NO $(30-100 \mathrm{nM})$ promote antiapoptotic and proliferative AKT and MAPK dependent pathway in cancer cells. In contrast, higher concentrations of NO (over $300 \mathrm{nM}$ ) promote apoptosis and antitumour activity. High ROS concentrations lower NO level resulting in a reduction of cell protection mechanisms against carcinogenesis (Marra et al., 2011).

The harmful effect of reactive oxygen species is diminished by enzymatic and non-enzymatic antioxidants. The most important enzymatic antioxidants are superoxide dismutase, catalase and glutathione peroxidase. Humans have three different types of superoxide dismutases: cytosolic $\mathrm{Cu}$-, $\mathrm{Zn}-\mathrm{SOD}$, mitochondrial Mn-SOD, and extracellular SOD (EC-SOD). Mn-SOD is one of the most efficient antioxidants with anti-tumour activity. Several observations indicated that Mn-SOD elevated level causes cancer retardation. A significant overexpression of Mn-SOD was found in gastrointestinal cancers. EC-SOD acts in a way coordinated by cytokines rather than in an individual way (Fang et al., 2002; Valko et al., 2006). A diminished activity of catalase was observed in the development of a variety of tumours. Glutathione is one of the most essential compounds of antioxidative protection. There are four types of Se-dependent glutathione peroxidases (GPx). They defeat $\mathrm{H}_{2} \mathrm{O}_{2}$ or organic peroxide ROOH. GPx also competes with catalase for $\mathrm{H}_{2} \mathrm{O}_{2}$ in a low oxidative stress conditions (Valko et al., 2006).

The non-enzymatic defence against oxidative stress involves vitamins (such as $\mathrm{C}$, E, and $\mathrm{D}_{3}$ ), carotenoids, and natural flavonoids. Many vitamins may inhibit production of NO by nitric oxide synthetases, supporting their anti-inflammatory and antiatherogenic properties. They can also directly scavenge ROS and upregulate activity of antioxidant enzymes (Fang et al., 2002). Vitamin C interacts in aqueous environment in human body with radicals and create tricarbonyl ascorbate free radical $\left(\mathrm{AscH}^{\circ}\right)$ which is a poorly reactive molecule. It has been also noticed that a high concentration of ascorbic acid exerts a positive effect in reducing the risk of stomach cancer, and plays a protective role in lung and colorectal cancer (Knekt et al., 1991). Vitamin E is fat soluble and exists in several forms and has the greatest antioxidant activity. A reduction of the incidence of colorectal cancer by diet supplementation with vitamin $\mathrm{E}$ was observed. It is also suggested that $\alpha$-tocopherol reacts together with ascorbic acid while preventing from oxidative stress. During antioxidant reaction $\alpha$-tocopherol is converted to an $\alpha$-tocopherol radical by donation of a labile hydrogen to lipid or lipid peroxyl radical. The $\alpha$-tocopherol radical is subsequently reduced to $\alpha$-tocopherol by ascorbic acid (Kojo, 2004; White et al., 1997). The most widely studied carotenoids connected with human disease preventing potential are $\beta$ carotene, lycopene crocetin, luthein and zeaxithin. Carotenoids may exert their effects by changing redox status through redox-sensitive cell signalling pathway. At a sufficiently high concentration they can also protect lipids from peroxidation. But carotenoids provide to be effective antioxidants only in low oxidative stress. There are also some studies that indicate their pro-oxidant abilities under the influence of high oxidation conditions (Kennedy and Liebler, 1992; Rice-Evans et al., 1997). Flavonoids are belived to have a great antioxidative potential. They can prevent lipids from peroxidation by donation of hydrogen atom to radicals $\mathrm{ROO}^{\bullet}$ resulting in the formation phenoxy radical intermediate. This intermediate is relatively stable so it does not propagate further radical reactions. Flavonoids are able to terminate chain reaction via interactions with other free radicals. They are also very effective peroxyl radicals scavengers. Diet supplementation with flavonoids such as quercetin and polyphenols is connected to lower rates of stomach, pancreatic, and lung cancer (Damianaki et al., 2000; Galati and O'Brien, 2004). 


\subsection{Oxidative stress in plants}

Plants are aerobic organisms and as such they use oxygen. An incomplete reduction of molecular oxygen leads to the emergence of highly reactive intermediates, reactive oxygen species, which are unavoidable byproducts of aerobic metabolism (Asada, 1987).

The major sites of ROS production in plant cells are chloroplasts, mitochondria, peroxisomes and apoplasts (Tab. 1). However, these are not the only sources of ROS - they can also be generated in cell walls and plasma membranes (Gill and Tuteja, 2010).

Table 1. Sites of ROS production in plants, partially adopted from Mittler 2002

\begin{tabular}{|c|c|c|c|}
\hline Site & Mechanism & $\begin{array}{c}\text { Primary ROI } \\
\text { (reactive oxygen } \\
\text { intermediates) }\end{array}$ & References \\
\hline \multirow{2}{*}{ Chloroplast } & Photosynthesis ET and PSI or II & $\mathrm{O}_{2}{ }^{--}$ & $\begin{array}{l}\text { (Asada, 1987) } \\
\text { (Asada, 1999) }\end{array}$ \\
\hline & Excited chlorophyll & ${ }^{1} \mathrm{O}_{2}$ & (Asada, 1987) \\
\hline Mitochondria & Respiration ET & $\mathrm{O}_{2}^{*-}$ & $\begin{array}{c}\text { (Dat et al., 2000a) } \\
\text { (Maxwell et al., 1999) }\end{array}$ \\
\hline \multirow{3}{*}{ Peroxisome } & Glycolate oxidase & $\mathrm{H}_{2} \mathrm{O}_{2}$ & (Corpas et al., 2001) \\
\hline & Fatty acid $\beta$-oxidation & $\mathrm{H}_{2} \mathrm{O}_{2}$ & (Corpas et al., 2001) \\
\hline & Xanthine oxidase & $\mathrm{O}_{2}{ }^{--}$ & (Corpas et al., 2001) \\
\hline \multirow{2}{*}{ Apoplast } & Oxalate oxidase & $\mathrm{H}_{2} \mathrm{O}_{2}$ & (Dat et al., 2000a) \\
\hline & Amine oxidase & $\mathrm{H}_{2} \mathrm{O}_{2}$ & (Allan and Fluhr, 1997) \\
\hline $\begin{array}{l}\text { Plasma } \\
\text { membrane }\end{array}$ & NADPH oxidase & $\mathrm{O}_{2}^{\cdot-}$ & $\begin{array}{c}\text { (Grant and Loake, 2000; } \\
\text { Hammond-Kosack and Jones, } \\
\text { 1996) }\end{array}$ \\
\hline Cell wall & Peroxidases, $\mathrm{Mn}^{2+}$ and NADH & $\mathrm{H}_{2} \mathrm{O}_{2}, \mathrm{O}_{2}^{--}$ & $\begin{array}{l}\text { (Grant and Loake, 2000; } \\
\text { Hammond-Kosack and Jones, } \\
\text { 1996) }\end{array}$ \\
\hline
\end{tabular}

As mentioned before, chloroplasts are major sites of ROS production. They are generated by the reaction centres of PSI and PSII in chloroplasts thylakoids (Asada, 2006). It was discovered that oxygen is photoreduced to hydrogen peroxide in PSI (Mehler, 1951). In a regular way, electron flow from excited photosystem centres is directed to $\mathrm{NADP}^{+}$, which is reduced to NADPH, subsequently entering the Calvin cycle and reducing $\mathrm{CO}_{2}$ (final electron acceptor). When the ETC is overloaded, a part of the electron flow is diverted from ferredoxin to $\mathrm{O}_{2}$, reducing it to $\mathrm{O}_{2}{ }^{--}$via Mehler reaction (Takahashi and Asada, 1988).

Recent research has linked chloroplast-produced ROS with hypersensitive response (HR) (Mur et al., 2008). Chloroplast-produced ROS have been shown to be capable of transmitting the spread of woundinduced PCD through maize tissues (Gray et al., 2002).

Plant mitochondria have specific electron transfer chain components and functions in processes such as photorespiration (Douce, 1989; Fernie et al., 2004; Hoefnagel, 1998; Moller, 2001; Noctor et al., 2007; Raghavendra and Padmasree, 2003; Rasmusson et al., 2004). ROS production in mitochondria takes place under normal respiratory conditions but can be enhanced in response to various biotic and abiotic 
stress conditions. Complex I and III of mitochondrial ETC are well know sites of $\mathrm{O}_{2}{ }^{--}$production, which can be subsequently reduced to $\mathrm{H}_{2} \mathrm{O}_{2}$ through SOD dismutation (Moller, 2001; Quan et al., 2008). This hydrogen peroxide can react with reduced $\mathrm{Fe}^{2+}$ and $\mathrm{Cu}^{+}$to produce highly toxic $\mathrm{OH}^{\circ}$, which can penetrate membranes and leave the mitochondrion (Greene, 2002; Rhoads et al., 2006; Sweetlove, 2004).

Mitochondria may play a central role in cell adaptation to abiotic stress, which is known to induce oxidative stress at the cellular level. It has been found that the energy-dissipating systems of durum wheat mitochondria diminish ROS production in those organelles. It was reported that an early generation of ROS can affect plant mitochondria by impairing metabolite transport, thus preventing further substrate oxidation, membrane potential generation and consequent large-scale ROS production (Pastore et al., 2002).

The main metabolic processes responsible for the generation of $\mathrm{H}_{2} \mathrm{O}_{2}$ in different types of peroxisomes are photorespiration glycolate oxidase reaction, fatty acid $\beta$-oxidation, the enzymatic reaction of flavin oxidases and the disproportionation of superoxide radicals (del Rio et al., 1992; Huang et al., 1983). Xanthine oxidase is responsible for the generation of superoxide radicals in the matrix of leaf peroxisomes (Sandalio et al., 1988). SOD scavenges $\mathrm{O}_{2}{ }^{-}$radicals and converts them into $\mathrm{O}_{2}$ and $\mathrm{H}_{2} \mathrm{O}_{2}$, which can be removed by catalase. Under certain stress conditions the activity of peroxisomal catalase can be strongly depressed (del Rio et al., 1996). There is an NADP(H)-dependent $\mathrm{O}_{2}{ }^{*}$ production site in the peroxisomal membrane, which is apparently formed by a small electron transport chain using $\mathrm{O}_{2}$ as an electron acceptor with the cytosolic production of $\mathrm{O}_{2}{ }^{-}$radicals (del Rio et al., 1998; Lopez-Huertas et al., 1999).

Other important ROS sources in plants are detoxification reactions catalysed by cytochrome P450 in cytoplasm and endoplasmic reticulum (McDowell and Dangl, 2000). ROS are also generated at the plasma membrane level (Bolwell, 1999; Bolwell and Wojtaszek, 1997) or extracellularly in apoplast in plants. pH-dependent cell wall-peroxidases, germin-like oxalate oxidases and amine oxidases have been proposed as $\mathrm{H}_{2} \mathrm{O}_{2}$ producers in apoplast of plant cells (Bolwell and Wojtaszek, 1997).

Redox signals are involved in all aspects of plant biology. They are key regulators of plant metabolism, morphology and development (Foyer and Noctor, 2003). Redox signals are particularly important in defence responses and cross-tolerance phenomena. One of the earliest events in the hypersensitive response, which is responsible for the activation and establishment of plant immunity to disease (Foyer and Noctor, 2003), is the rapid accumulation of ROS through the activation of enzyme systems (Keller et al., 1998). The oxidative burst is a central component of an integrated HR signalling system, whose function is rapid amplification of the signal (Foyer and Noctor, 2003).

The absolute rate of $\mathrm{H}_{2} \mathrm{O}_{2}$ production and the rate of scavenging by detoxifying systems are likely to be the main determinants of $\mathrm{H}_{2} \mathrm{O}_{2}$ concentration. A possible key determinant of signalling intensity is $\mathrm{H}_{2} \mathrm{O}_{2}$ ability to react with signalling compounds. $\mathrm{H}_{2} \mathrm{O}_{2}$ mediates intra- and extra-cellular communication during plant reactions to pathogens and several studies have suggested its role in systemic acquired resistance. Antioxidants and/or antioxidative enzymes are likely to take part in the early step of redox signalling (Foyer and Noctor, 2003). Glutathione and ascorbate are also suggested to be involved in this process in plants (Baier et al., 2000; Horling, 2003; Noctor et al., 2000). Specific compartment-based signalling and regulation of gene expression can be achieved via differential compartment-based changes in either the absolute concentrations of ascorbate and glutathione or ascorbate/dehydroascorbate and GSH/GSSG ratios, which are very high and stable in normal state (Noctor et al., 2000).

It is suggested that redox signalling is a key function of the cytoplasmic genome found in chloroplasts and mitochondria, along with the exchange of redox information between these organelles and the nucleus (Foyer and Noctor, 2003). An interesting thing is that genes most strongly induced by stress 
conditions are not necessarily those coding antioxidant defence system compounds. Induced genes coding the enzymatic antioxidants often tend to encode cytosolic rather than chloroplastic antioxidative proteins, even if the stress is predicted to be located in chloroplasts (Foyer and Noctor, 2003). Peroxisomes are known to release signals that regulate nuclear gene expression. Signals arising from peroxisomes regulate photomorphogenesis, plant development peroxisomal biogenesis, light signalling and stress responses (Hu et al., 2002).

While growing, plants are often exposed to adverse environmental conditions, namely biotic and abiotic stresses. Many of them give rise to the overproduction of reactive oxygen species (ROS). Many stress-related symptoms are exacerbated, if not directly dependent on ROS (Dat et al., 2000a).

High-light exposure is one of the most common sources of oxidative stress in plants (Foyer et al., 1994). Expression analysis of antioxidants has provided evidence for accumulation of ROS during high-light exposure. Strong induction of chloroplastic Fe-SOD transcripts has been observed in tobacco plants exposed to high light (Tsang et al., 1991). Fe-SOD mRNA increase was not light dependent but directly responsive to oxidative stress. Activities of most antioxidant enzymes increased in pea seedling after transfer from low to high light (Mishra et al., 1995). A degradation of glutamine synthetase, phosphoglycolate phosphatise, a large subunit of ribulose-1,5-biphosphate carboxylase/oxygenase, and an increased content of carbonyl groups in stromal proteins of pea during high-light treatment is an additional evidence for an involvement of ROS, as all these processes result from oxidative damage (Stieger and Feller, 1997).

Drought-induced inhibition of photosynthesis leads to increased ROS production in chloroplasts (Leprince, 1994; Smirnoff, 1993, 1998). The accumulation of ROS during such conditions originates mainly from a decline in $\mathrm{CO}_{2}$ fixation, leading to higher leakage of electrons to $\mathrm{O}_{2}$. Increased thylakoid membrane electron leakage to $\mathrm{O}_{2}$ has been observed in sunflower (Sgherri et al., 1996) and in wheat (Biehler and Fock, 1996) after water deficiency conditions. ROS-dependent changes associated with water deficit (Aziz and Larher, 1998; Gogorcena et al., 1995; Iturbe-Ormaetxe et al., 1998; Moran et al., 1994) as well as levels of antioxidants (Gogorcena et al., 1995; Olsson, 1995; Schwanz et al., 1996) have been reported. Activities of cytosolic and chloroplastic $\mathrm{Cu} / \mathrm{Zn}$-SOD and cytosolic APX rise during drought of pea plants (Mittler and Zilinskas, 1992, 1994), and osmotic stress enhance Mn-SOD transcript abundance in maize (Zhu and Scandalios, 1994).

Plant response to salt stress often resembles that of the drought-mediated one. The generation of ROS during salt stress is probably similar to that during drought and is mainly attributed to increased leakage of electrons to $\mathrm{O}_{2}$ (Dat et al., 2000a). An increase of $\mathrm{H}_{2} \mathrm{O}_{2}$ concentrations in rice shoot tissue has been reported upon salt stress (Fadzilla et al., 1997). The amounts of mitochondrial and chloroplastic SOD and APX isozymes increase during salt stress in pea (Hernandez et al., 1993; Hernandez et al., 1995).

Low temperature is one of many studied abiotic types of stress in plants Direct evidence for ROS accumulation during chilling was reported for several plant species. Chloroplast is a major source of ROS during low temperature treatment through the nhibition of $\mathrm{CO}_{2}$ fixation. Mitochondrial ROS accumulation in the same conditions has also been demonstrated (De Santis et al., 1999; GonzalezMeler et al., 1999; Prasad et al., 1995). A transient but significant increase of $\mathrm{H}_{2} \mathrm{O}_{2}$ level induced by cold treatment of winter wheat has been showed (Okuda et al., 1991). $\mathrm{H}_{2} \mathrm{O}_{2}$ accumulation in chilled cucumber plants (Omran, 1980) and maize seedlings was observed (Prasad et al., 1994). Chilling of callus tissue of Arabidopsis thaliana also resulted in oxidative stress (O'Kane et al., 1996).

High-temperature exposure involves ROS accumulation as well. It was shown that an oxidative burst occurred in potato leaf tissues after heat shock. A significant increase in $\mathrm{H}_{2} \mathrm{O}_{2}$ level was induced after heat treatment in whole tobacco seedlings (Dat et al., 2000b; Foyer et al., 1997). A similar observation of $\mathrm{H}_{2} \mathrm{O}_{2}$ accumulation after heat treatment was made for mustard seedlings (Dat et al., 1998). Changes in antioxidants during high-temperature treatment have also been reported. For example, SOD level 
increases in heat-treated tobacco (Tsang et al., 1991). High activities of APX and GR improve the heat protection of wheat (Kraus and Fletcher, 1994).

Heavy metals, like copper, aluminium, cadmium, zinc and iron, may cause oxidative stress. An excessive amount of copper causes ROS formation and lipid peroxidation (De Vos et al., 1992; Halliwell and Gutteridge, 1989; Sandmann and Boger, 1980; Weckx and Clijsters, 1996). ROS accumulation during $\mathrm{Cu}$ stress is suggested by differential activation of SOD in tobacco (Kurepa et al., 1997) and soybean (Chongpraditnun et al., 1992) after $\mathrm{Cu}$ treatment. Aluminium also causes ROSmediated lipid peroxidation (Kochian, 1995). Aluminium induces glutathione S-transferase (GST), peroxidase, $\beta$-1,3-glucanase, PR2, and phenylalanine ammonia lyase in Arabidopsis thaliana (Richards et al., 1998), and several antioxidant gene transcripts in soybean (Cakmak and Horst, 1991). Zinc treatment caused increased levels of $\mathrm{H}_{2} \mathrm{O}_{2}$ in roots and lipid peroxidation in primary leaves of Phaseolus vulgaris (Weckx and Clijsters, 1997). Iron excess can also result in oxidative stress (Halliwell and Gutteridge, 1989). It is due to its potential for reacting with $\mathrm{H}_{2} \mathrm{O}_{2}$ and $\mathrm{O}_{2}{ }^{-}$to generate $\mathrm{OH}^{*}$. An increased activity of catalase and APX was observed in tobacco seedlings after iron excess (Kampfenkel et al., 1995). Iron-induced oxidative stress in maize was proposed as a possible trigger for ferritin mRNA and protein accumulation (Lobreaux et al., 1995).

Chemical compounds used in plant cultivation are linked to oxidative stress. It has been reported that maize leaves exposed to glyphosate had an increased level of lipid peroxidation, glutathione (GSH), free Proline content, and ion flux, suggesting, that besides the inhibition of its specific target, which is 5-enolpyruvylshikimate-3-phosphate synthase (EPSPS) (Ahsan et al., 2008; Schonbrunn et al., 2001), this treatment leads to oxidative stress in plants (Sergiev et al., 2006). Upregulation of some antioxidant enzymes was identified, including glutathione S-transferase, ascorbate peroxidase, thioredoxin $h$-type, nucleoside diphosphate kinase 1 (NDPK1), peroxiredoxin, or their precursor such as superoxide dismutase chloroplast precursor after paraquat treatment (Ahsan et al., 2008). A significant upregulation for those enzymes after glyphosate treatment was observed, which supports the idea that plants also utilised antioxidant defence mechanisms to protect against glyphosate stress. Authors also noted different expression for two different isozymes of GST. Two APX isoforms and a $\mathrm{Cu} / \mathrm{Zn}$-SOD chloroplast precursor were significantly upregulated by treatment with both glyphosate and paraquat, as well as thioredoxin $h$ and peroxiredoxin (Ahsan et al., 2008). It was suggested that exposure to glyphosate causes oxidative stress resulting in lipid peroxidation and subsequent membrane damage (Ahsan et al., 2008). It was suggested that glyphosate promotes harmful effects on non-target species of Chlorella kessleri through oxidative stress. A significant increase in the amount of malondialdehyde (MDA) was observed (Romero et al., 2011), indicating damage of lipid membranes (Janero, 1990). The level of GSH was also increased, which suggests GSH involvement in the antioxidant defence upon glyphosate exposure in Chlorella kessleri (Romero et al., 2011). The increase of GSH amount in plants treated with glyphosate was reported earlier (Jain and Bhalla-Sarin, 2001; Uotila et al., 1995).

UV radiation induces the production of $\mathrm{O}_{2}{ }^{-}$, which can be subsequently dismutated by SOD to $\mathrm{H}_{2} \mathrm{O}_{2}$ (Murphy and Huerta, 1990). In Nicotiana plubaginofolia exposure to UV-B caused a significant increase in Cat2 and GPX mRNA, while APX and SOD transcript levels remain relatively unaltered (Willekens et al., 1994). In Pisum sativum SOD transcript levels decrease after UV-B exposure, but those of GPX are higher (Strid, 1993).

Wound-induced ROS accumulation in various species is inhibited by diphenyleneiodonium, an NADPH-oxidase inhibitor, which suggests it is NADP(H) dependent (Orozco-Cardenas and Ryan, 1999). Wounding stimulates $\mathrm{H}_{2} \mathrm{O}_{2}$ generation systemically in tomato leaves (Orozco-Cardenas and Ryan, 1999). ROS accumulation resulting from mechanical stress was reported for various species (Schopfer, 1994; Watanabe and Sakai, 1998). 
The active defence of plants against invading pathogens often includes rapid and localised cell death, known as hypersensitive response (Liu et al., 2007). ROS production, altered ion fluxes, protein phosphorylation and dephosphorylation, and gene activation have been implicated in the HR process (Liu et al., 2007). An involvement of protein kinases in HR cell death induced by both avirulent pathogens and pathogen-associated molecular patterns (PAMPs) was suggested (Liu et al., 2007). ROS generation after MAPK activation connection to induction of HR cell death was suggested (Ren et al., 2002). It was demonstrated that the generation of ROS after MAPK activation is preceded by a disruption of metabolic activities in chloroplasts and mitochondria. Scientists found that pathogenresponsive NtMEK2-SIPK/Ntf4/WIPK cascade plays an active role in promoting ROS generation in chloroplasts by inhibiting the carbon fixation (Liu et al., 2007). An alteration in the expression or activity of ROS-scavenging enzymes has been indicated as a key step in the activation of phytopathogen defence (Da Gara et al., 2003). ROS can act directly against phytopathogen attack by killing microorganisms. $\mathrm{H}_{2} \mathrm{O}_{2}$ contributes to wall stiffening by facilitating peroxidase reactions catalysing intra- and intermolecular cross-links between structural components of cell walls and lignin polymerisation (Ros Barcelo, 1997), thus hindering and slowing down pathogen penetration in plant tissue, which allows plant cells to arrange defence that requires more time to be activated. $\mathrm{H}_{2} \mathrm{O}_{2}$ is diffusible in biological membranes, hence it also acts as intracellular signal, which is able to activate defence responses (Durner et al., 1997). It seems that, in contradiction to most abiotic stress response based on ROS-scavenging system enhancement, pathogen-attack response is dependent rather on ROSscavenging system suppression, which allows plant cells to prevent from pathogen penetration using an extremely oxidative local environment (Da Gara et al., 2003).

\section{CONCLUSIONS}

For many years ROS have been considered as inevitable byproducts of the metabolism of aerobic organisms. However, recently it has become obvious that they are very important and necessary for many cellular processes. ROS participate in regular processes, including growth, development and signalling. When the equilibrium between ROS production and scavenging is disturbed, oxidative stress occurs. It is involved in the aetiology of many human diseases and different stress response patterns in plants.

To date, there is extensive knowledge about ROS and oxidative stress in cells, yet much more needs to be elucidated. Hopefully, future research will give us a better understanding of all the mechanisms and components involved in ROS production, usage and function.

This work was supported by grants from Polish Ministry of Science and Higher Education No NN310043738, NN310769840 and NN401579840

\section{REFERENCES}

Ahsan N., Lee D.G., Lee K.W., Alam, I., Lee, S.H., Bahk, J.D., Lee, B.H., 2008. Glyphosate-induced oxidative stress in rice leaves revealed by proteomic approach. Plant Physiol. Bioch., 46, 1062-1070. DOI: 10.1016/j.plaphy.2008.07.002.

Alam. Z.I., Jenner. A., Daniel. S.E., Lees. A.J., Cairns. N., Marsden. C.D., Jenner. P., Halliwell. B., 1997. Oxidative DNA damage in the parkinsonian brain: an apparent selective increase in 8-hydroxyguanine levels in substantia nigra. J. Neurochem., 69, 1196-1203. DOI: 10.1046/j.1471-4159.1997.69031196.x.

Allan. A.C., Fluhr. R., 1997. Two distinct sources of elicited reactive oxygen species in tobacco epidermal cells. Plant Cell, 9, 1559-1572. DOI: 10.1105/tpc.9.9.1559.

Apel. K., Hirt. H., 2004. Reactive oxygen species: metabolism, oxidative stress, and signal transduction. Annu. Rev. Plant Biol., 55, 373-399. DOI: 10.1146/annurev.arplant.55.031903.141701. 


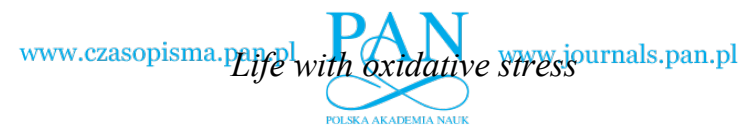

Asada K., 1999. The water-water cycle in chloroplasts: Scavenging of active oxygens and dissipation of excess photons. Annu. Rev. Plant Physiol. Plant Mol. Biol., 50, 601-639. DOI: 10.1146/annurev.arplant.50.1.601.

Asada K., 2006. Production and scavenging of reactive oxygen species in chloroplasts and their functions. Plant Physiol., 141, 391-396. DOI: 10.1104/pp.106.082040.

Asada K., Takahashi M., 1987. Production and scavenging of active oxygen in photosynthesis, In: Kyle D.J., Osmond C.B., Arntzen C. J. (Eds.), Photoinhibition. Elsevier, Amsterdam, 227-287.

Atwood C.S., Perry G., Zeng H., Kato Y., Jones W.D., Ling K.Q., Huang X., Moir R.D., Wang D., Sayre L.M., Smith M.A., Chen S.G., Bush A.I., 2004. Copper mediates dityrosine cross-linking of Alzheimer's amyloid- $\beta$. Biochemistry, 43, 560-568. DOI: 10.1021/bi0358824.

Avery S.V., 2011. Molecular targets of oxidative stress. Biochem. J., 434, 201-210. DOI: 10.1042/BJ20101695.

Aziz A., Larher F., 1998. Osmotic stress induced changes in lipid composition and peroxidation in leaf discs of Brassica napus L. J. Plant Physiol., 153, 754-762. DOI: 10.1016/S0176-1617(98)80231-9.

Badawi G.H., Kawano N., Yamauchi Y., Shimada E., Sasaki R., Kubo A., Tanaka K., 2004. Over-expression of ascorbate peroxidase in tobacco chloroplasts enhances the tolerance to salt stress and water deficit. Physiol. Plant, 121, 231-238. DOI: 10.1111/j.0031-9317.2004.00308.x.

Baier M., Noctor G., Foyer C.H., Dietz K.J., 2000. Antisense suppression of 2-cysteine peroxiredoxin in Arabidopsis specifically enhances the activities and expression of enzymes associated with ascorbate metabolism but not glutathione metabolism. Plant Physiol., 124, 823-832. DOI: 10.1104/pp.124.2.823.

de Beer M.C., Zhao Z., Webb N.R., van der Westhuyzen D.R., de Villiers W.J., 2003. Lack of a direct role for macrosialin in oxidized LDL metabolism. J. Lipid Res., 44, 674-685. DOI: 10.1194/j1r.M200444-JLR200.

Biehler K., Fock H., 1996. Evidence for the contribution of the Mehler-peroxidase reaction in dissipating excess electrons in drought-stressed wheat. Plant Physiol., 112, 265-272. DOI: 10.1104/pp.112.1.265.

Bolwell G.P., 1999. Role of active oxygen species and NO in plant defence responses. Curr. Opin. Plant Biol., 2, 287-294. DOI: 10.1016/S1369-5266(99)80051-X.

Bolwell G.P., Wojtaszek P., 1997. Mechanisms for the generation of reactive oxygen species in plant defence - a broad perspective. Physiol. Mol. Plant P, 51, 347-366. DOI: 10.1006/pmpp.1997.0129.

Britt A.B., 1999. Molecular genetics of DNA repair in higher plants. Trends Plant Sci., 4, 20-25. DOI: 10.1016/S1360-1385(98)01355-7.

Cadenas E., 1989. Biochemistry of oxygen toxicity. Annu. Rev. Biochem., 58, 79-110. DOI: 10.1146/annurev.bi.58.070189.000455.

Cakmak I., Horst W.J., 1991. Effect of aluminium on lipid peroxidation, superoxide dismutase, catalase, and peroxidase activities in root tips of soybean (Glycine max). Physiol. Planarum, 83, 463-468. DOI: 10.1111/j.1399-3054.1991.tb00121.x.

Cecarini V., Gee J., Fioretti E., Amici M., Angeletti M., Eleuteri A.M., Keller J.N., 2007. Protein oxidation and cellular homeostasis: Emphasis on metabolism. Biochim. Biophys. Acta, 1773, 93-104. DOI: 10.1016/j.bbamcr.2006.08.039.

Chan A., Shea T.B., 2006. Supplementation with apple juice attenuates presenilin-1 overexpression during dietary and genetically-induced oxidative stress. J. Alzheimers Dis., 10, 353-358. DOI: 10.1177/1533317510363470.

Chang Y., Kong Q., Shan X., Tian G., Ilieva H., Cleveland D.W., Rothstein J.D., Borchelt D.R., Wong P.C., Lin C.L., 2008. Messenger RNA oxidation occurs early in disease pathogenesis and promotes motor neuron degeneration in ALS. PLoS One, 3, e2849.

Chongpraditnun P., Mori S., Chino M., 1992. Excess copper induces a cytosolic Cu, Zn-superoxide dismutase in soybean root. Plant Cell Physiol., 33, 239-244.

Corpas F.J., Barroso J.B., del Rio L.A., 2001. Peroxisomes as a source of reactive oxygen species and nitric oxide signal molecules in plant cells. Trends Plant Sci., 6, 145-150. DOI: 10.1016/S1360-1385(01)01898-2.

Damianaki A., Bakogeorgou E., Kampa M., Notas G., Hatzoglou A., Panagiotou S., Gemetzi C., Kouroumalis E., Martin P.M., Castanas E., 2000. Potent inhibitory action of red wine polyphenols on human breast cancer cells. J. Cell. Biochem., 78, 429-441. DOI: 10.1002/1097-4644(20000901)78:3<429::AID-JCB8>3.0.CO;2-M.

Dat J., Vandenabeele S., Vranova E., Van Montagu M., Inze D., Van Breusegem F., 2000a. Dual action of the active oxygen species during plant stress responses. Cell. Mol. Life Sci., 57, 779-795. DOI: $10.1007 / \mathrm{s} 000180050041$.

Dat J.F., Lopez-Delgado H., Foyer C.H., Scott I.M., 1998. Parallel changes in $\mathrm{H}_{2} \mathrm{O}_{2}$ and catalase during thermotolerance induced by salicylic acid or heat acclimation in mustard seedlings. Plant Physiol., 116, 13511357. DOI: $10.1104 / p p .116 .4 .1351$. 
Dat J.F., Lopez-Delgado H., Foyer C.H., Scott I.M., 2000b. Effects of salicylic acid on oxidative stress and thermotolerance in tobacco. J. Plant Physiol., 156, 659-665. DOI: 10.1016/S0176-1617(00)80228-X.

Doke N., 1997. The oxidative burst: roles in signal transduction and plant stress, In: Scandalios J.G. (Eds.), Oxidative stress and the molecular biology of antioxidant defenses. Cold Spring Harbour Laboratory Press, Cold Spring Harbour, NY. DOI: 10.1101/087969502.34.785.

Donahue J.L., Okpodu C.M., Cramer C.L., Grabau E.A., Alscher R.G., 1997. Responses of antioxidants to paraquat in pea leaves (relationships to resistance). Plant Physiol., 113, 249-257. DOI: 10.1104/pp.113.1.249.

Douce R., Neuberger M., 1989. The uniqueness of plant mitochondria. Annu. Rev. Plant Physiol. Plant Mol. Biol., 40, 371-414. DOI: 10.1146/annurev.pp.40.060189.002103.

Durner J., Shah J., Klessig D.F., 1997. Salicylic acid and disease resistance in plants. Trends Plant Sci., 2, 266274. DOI: 10.1016/S1360-1385(97)86349-2.

Evans P., Halliwell B., 1999. Free radicals and hearing: Cause, consequence, and criteria. Ann. NY Acad. Sci., 884, 19-40. DOI: 10.1111/j.1749-6632.1999.tb08633.x.

Fadzilla N.M., Finch R.P., Burdon R.H., 1997. Salinity, oxidative stress and antioxidant responses in shoot cultures of rice. J. Exp. Botany, 48, 325-331. DOI: 10.1093/jxb/48.2.325.

Fang Y.Z., Yang S., Wu G., 2002. Free radicals, antioxidants, and nutrition. Nutrition, 18, 872-879. DOI: 10.1016/S0899-9007(02)00916-4.

Feild T.S., Nedbal L., Ort D.R., 1998. Nonphotochemical reduction of the plastoquinone pool in sunflower leaves originates from chlororespiration. Plant Physiol., 116, 1209-1218. DOI: 10.1104/pp.116.4.1209.

Fernie A.R., Carrari F., Sweetlove L.J., 2004. Respiratory metabolism: glycolysis, the TCA cycle and mitochondrial electron transport. Curr. Opin. Plant Biol., 7, 254-261. DOI: 10.1016/j.pbi.2004.03.007.

Flors C., Nonell S., 2006. Light and singlet oxygen in plant defense against pathogens: phototoxic phenalenone phytoalexins. Acc. Chem. Res., 39, 293-300. DOI: 10.1021/ar0402863.

Fones H., Preston G.M., 2012. Reactive oxygen and oxidative stress tolerance in plant pathogenic Pseudomonas. FEMS Microbiol. Lett., 327, 1-8. DOI: 10.1111/j.1574-6968.2011.02449.x.

Foyer C.H., Descourvieres P., Kunert K.J., 1994. Protection against oxygen radicals: an important defence mechanism studied in transgenic plants. Plant Cell Environ., 17, 507-523. DOI: 10.1111/j.13653040.1994.tb00146.x.

Foyer C.H., Lopez-Delgado H., Dat J.F., Scott I.M., 1997. Hydrogen peroxide- and glutathione-associated mechanisms of acclimatory stress tolerance and signalling. Physiol. Plant, 100, 241-254. DOI: 10.1111/j.13993054.1997.tb04780.x.

Foyer C.H., Noctor G., 2003. Redox sensing and signalling associated with reactive oxygen in chloroplasts, peroxisomes and mitochondria. Physiol. Plant, 119, 355-364. DOI: 10.1034/j.1399-3054.2003.00223.x.

Galati G., O'Brien P.J., 2004. Potential toxicity of flavonoids and other dietary phenolics: significance for their chemopreventive and anticancer properties. Free Radic. Biol. Med., 37, 287-303. DOI: 10.1016/j.freeradbiomed.2004.04.034.

De Gara L., de Pinto M.C., Tommasi F., 2003. The antioxidant systems vis-à-vis reactive oxygen species during plant-pathogen interaction. Plant Physiol. Bioch., 41, 863-870. DOI: 10.1016/S0981-9428(03)00135-9.

Ghezzi P., Bonetto V., 2003. Redox proteomics: Identification of oxidatively modified proteins. Proteomics, 3, 1145-1153. DOI: 10.1002/pmic.200300435.

Gill S.S., Tuteja N., 2010. Reactive oxygen species and antioxidant machinery in abiotic stress tolerance in crop plants. Plant Physiol. Biochem., 48, 909-930. DOI: 10.1016/j.plaphy.2010.08.016.

Gogorcena Y., Iturbe-Ormaetxe I., Escuredo P.R., Becana M., 1995. Antioxidant defenses against activated oxygen in pea nodules subjected to water-stress. Plant Physiol., 108, 753-759. DOI: 10.1104/pp.108.2.753.

Gonzalez-Meler M.A., Ribas-Carbo M., Giles L., Siedow J.N., 1999. The effect of growth and measurement temperature on the activity of the alternative respiratory pathway. Plant Physiol., 120, 765-772. DOI: 10.1104/pp.120.3.765.

Goyal T., Mitra S., Khaidakov M., Wang X., Singla S., Ding Z., Liu S., Mehta J.L., 2012. Current concepts of the role of oxidized LDL receptors in atherosclerosis. Curr. Atheroscler. Rep., 14, 150-159. DOI: 10.1007/s11883012-0228-1.

Grant J.J., Loake G.J., 2000. Role of reactive oxygen intermediates and cognate redox signaling in disease resistance. Plant Physiol., 124, 21-29. DOI: 10.1104/pp.124.1.21.

Gray J., Janick-Buckner D., Buckner B., Close P.S., Johal G.S., 2002. Light-dependent death of maize $l l s 1$ cells is mediated by mature chloroplasts. Plant Physiol., 130, 1894-1907. DOI: 10.1104/pp.008441. 
Greene R., 2002. Oxidative stress and acclimation mechanisms in plants. Arabidopsis Book, 1, BioOne Publishers, Washington, 11-20. DOI: 10.1199/tab.0036.1.

Halliwell B., 1981. The biological effects of the superoxide radical and its products. Bull. Eur. Physiopathol. Respir., 17 Suppl, 21-29.

Halliwell B., 1999. Antioxidant defence mechanisms: from the beginning to the end (of the beginning). Free Radic. Res., 31, 261-272. DOI: 10.1080/10715769900300841.

Halliwell B., 2006. Reactive species and antioxidants. Redox biology is a fundamental theme of aerobic life. Plant Physiol., 141, 312-322. DOI: 10.1104/pp.106.077073.

Halliwell B., Gutteridge J.M.C., 1989. Free radicals in biology and medicine. 2nd edition, Clarendon Press, Oxford University Press, Oxford, New York, xvi, 543 p.

Hammond-Kosack K.E., Jones J.D., 1996. Resistance gene-dependent plant defense responses. Plant Cell, 8 , 1773-1791. DOI: $10.1105 /$ tpc.8.10.1773.

Hernandez J.A., Corpas F.J., Gomez M., del Rio L.A., Sevilla F., 1993. Salt-induced oxidative stress mediated by activated oxygen species in pea leaf mitochondria. Physiol. Plant, 89, 103-110. DOI: 10.1111/j.13993054.1993.tb01792.x.

Hernandez J.A., Olmos E., Corpas F.J., Sevilla F., del Rio L.A., 1995. Salt-induced oxidative stress in chloroplasts of pea plants. Plant Sci., 105, 151-167. DOI: 10.1016/0168-9452(94)04047-8.

Hoefnagel M.H.N., Atkin O.K., Wiskich J.T., 1998. Interdependence between chloroplasts and mitochondria in the light and in the dark. Bochim. Biophys. Acta, 1336, 235-255. DOI: 10.1016/S0005-2728(98)00126-1.

Horling F., Lamkemeyer P., Konig J., Finkemeuer I., Kandlbinder A., Baier M., Dietz K.J., 2003. Divergent light-, ascorbate- and oxidative stress-dependent regulation of expression of the peroxiredoxin gene family in Arabidopsis. Plant Physiol., 131. DOI: 10.1104/pp.010017.

Hu J. P., Aguirre M., Peto C., Alonso J., Ecker J., Chory J., 2002. A role for peroxisomes in photomorphogenesis and development of Arabidopsis. Sci., 297, 405-409. DOI: 10.1126/science.1073633.

Huang A.H.C., Trelease R.N., Moore T.S., 1983. Plant peroxisomes. Academic Press, New York, xiii, 252 p.

Iturbe-Ormaetxe I., Escuredo P.R., Arrese-Igor C., Becana M., 1998. Oxidative damage in pea plants exposed to water deficit or paraquat. Plant Physiol., 116, 173-181. DOI: 10.1104/pp.116.1.173.

Jain M., Bhalla-Sarin N., 2001. Glyphosate-induced increase in glutathione $S$-transferase activity and glutathione content in groundnut (Arachis hypogaea L.). Pestic. Biochem. Phys., 69, 143-152. DOI: 10.1006/pest.2000.2535.

Janero D.R., 1990. Malondialdehyde and thiobarbituric acid-reactivity as diagnostic indices of lipid peroxidation and peroxidative tissue injury. Free Radic. Biol. Med., 9, 515-540. DOI: 10.1016/0891-5849(90)90131-2.

Kamal-Eldin A., Appelqvist L.A., 1996. The chemistry and antioxidant properties of tocopherols and tocotrienols. Lipids, 31, 671-701. DOI: 10.1007/BF02522884.

Kampfenkel K., Van Montagu M., Inze D., 1995. Effects of iron excess on Nicotiana plumbaginifolia plants (implications to oxidative stress). Plant Physiol., 107, 725-735. DOI: 10.1104/pp.107.3.725.

Keller T., Damude H.G., Werner D., Doerner P., Dixon R.A., Lamb C., 1998. A plant homolog of the neutrophil NADPH oxidase gp91 ${ }^{\text {phox }}$ subunit gene encodes a plasma membrane protein with $\mathrm{Ca}^{2+}$ binding motifs. Plant Cell, 10, 255-266. DOI: 10.1105/tpc.10.2.255.

Kennedy T.A., Liebler D.C., 1992. Peroxyl radical scavenging by beta-carotene in lipid bilayers. Effect of oxygen partial pressure. J. Biol. Chem., 267, 4658-4663.

Knekt P., Jarvinen R., Seppanen R., Rissanen A., Aromaa A., Heinonen O.P., Albanes D., Heinonen M., Pukkala E., Teppo L., 1991. Dietary antioxidants and the risk of lung cancer. Am. J. Epidemiol., 134, 471-479.

Kochian L.V., 1995. Cellular mechanisms of aluminum toxicity and resistance in plants. Annu. Rev. Plant Physiol. Plant Mol. Biol., 46, 237-260. DOI: 10.1146/annurev.pp.46.060195.001321.

Kojo S., 2004. Vitamin C: basic metabolism and its function as an index of oxidative stress. Curr. Med. Chem., 11, 1041-1064. DOI: 10.2174/0929867043455567.

Kong Q., Lin C.L., 2010. Oxidative damage to RNA: mechanisms, consequences, and diseases. Cell Mol. Life Sci., 67, 1817-1829. DOI: 10.1007/s00018-010-0277-y.

Kovacic P., Pozos R.S., 2006. Cell signaling (mechanism and reproductive toxicity): Redox chains, radicals, electrons, relays, conduit, electrochemistry, and other medical implications. Birth Defects Res. Part C: Embryo Today: Rev., 78, 333-344. DOI: 10.1002/bdrc.20083.

Kraus T.E., Fletcher R.A., 1994. Paclobutrazol protects wheat seedlings from heat and paraquat injury. Is detoxification of active oxygen involved. Plant Cell Physiol., 35, 45-52. 
Kurepa J., Herouart D., Van Montagu M., Inze D., 1997. Differential expression of CuZn- and Fe-superoxide dismutase genes of tobacco during development, oxidative stress, and hormonal treatments. Plant Cell Physiol., $38,463-470$.

Leprince O., Hendry G.A.F., Atherton N.M., 1994. Free radical processes induced by desiccation in germinating maize: the relationship with respiration and loss of desiccation tolerance. Proc. R. Soc. Edinb. B, 102, 211-218. DOI: $10.1017 / \mathrm{S} 0269727000014135$.

Li Z., Wu J., Deleo C.J., 2006. RNA damage and surveillance under oxidative stress. IUBMB Life, 58, 581-588. DOI: $10.1080 / 15216540600946456$.

Liu Y., Ren D., Pike S., Pallardy S., Gassmann W., Zhang S., 2007. Chloroplast-generated reactive oxygen species are involved in hypersensitive response-like cell death mediated by a mitogen-activated protein kinase cascade. Plant J., 51, 941-954. DOI: 10.1111/j.1365-313X.2007.03191.x.

Lobreaux S., Thoiron S., Briat J.F., 1995. Induction of ferritin synthesis in maize leaves by an iron-mediated oxidative stress. Plant J., 8, 443-449. DOI: 10.1046/j.1365-313X.1995.08030443.x.

Lopez-Huertas E., Corpas F.J., Sandalio L.M., del Rio L.A., 1999. Characterization of membrane polypeptides from pea leaf peroxisomes involved in superoxide radical generation. Biochem J., 337 ( Pt 3), 531-536. DOI: 10.1042/0264-6021:3370531.

Magder S., 2006. Reactive oxygen species: toxic molecules or spark of life? Crit. Care, 10, 208. DOI: $10.1186 / \mathrm{cc} 3992$.

Marra M., Sordelli I.M., Lombardi A., Lamberti M., Tarantino L., Giudice A., Stiuso P., Abbruzzese A., Sperlongano R., Accardo M., Agresti M., Caraglia M., Sperlongano P., 2011. Molecular targets and oxidative stress biomarkers in hepatocellular carcinoma: an overview. J. Transl. Med., 9, 171. DOI: 10.1186/1479-5876-9171.

Martinet W., de Meyer G.R., Herman A.G., Kockx M.M., 2004. Reactive oxygen species induce RNA damage in human atherosclerosis. Eur. J. Clin. Invest., 34, 323-327. DOI: 10.1111/j.1365-2362.2004.01343.x.

Martinet W., De Meyer G.R., Herman A.G., Kockx M.M., 2005. Amino acid deprivation induces both apoptosis and autophagy in murine C2C12 muscle cells. Biotechno.l Lett., 27, 1157-1163. DOI: 10.1007/s10529-0050007-y.

Martinet W., Knaapen M.W., De Meyer G.R., Herman A.G., Kockx M.M., 2002. Elevated levels of oxidative DNA damage and DNA repair enzymes in human atherosclerotic plaques. Circulation, 106, 927-932. DOI: 10.1161/01.CIR.0000026393.47805.21.

Maxwell D.P., Wang Y., McIntosh L., 1999. The alternative oxidase lowers mitochondrial reactive oxygen production in plant cells. Proc. Natl. Acad. Sci. USA, 96, 8271-8276. DOI: 10.1073/pnas.96.14.8271.

McDowell J.M., Dangl J.L., 2000. Signal transduction in the plant immune response. Trends Biochem. Sci., 25, 79-82. DOI: 10.1016/S0968-0004(99)01532-7.

Mehler A.H., 1951. Studies on reactions of illuminated chloroplasts. II. Stimulation and inhibition of the reaction with molecular oxygen. Arch. Biochem. Biophys., 34, 339-351. DOI: 10.1016/0003-9861(51)90012-4.

Mishra N.P., Fatma T., Singhal G.S., 1995. Development of antioxidative defense system of wheat seedlings in response to high light. Physiol. Plant, 95, 77-82. DOI: 10.1111/j.1399-3054.1995.tb00811.x.

Mittler R., 2002. Oxidative stress, antioxidants and stress tolerance. Trends Plant Sci., 7, 405-410. DOI: 10.1016/S1360-1385(02)02312-9.

Mittler R., Vanderauwera S., Gollery M., Van Breusegem F., 2004. Reactive oxygen gene network of plants. Trends Plant Sci., 9, 490-498. DOI: 10.1016/j.tplants.2004.08.009.

Mittler R., Zilinskas B.A., 1992. Molecular cloning and characterization of a gene encoding pea cytosolic ascorbate peroxidase. J. Biol. Chem., 267, 21802-21807.

Mittler R., Zilinskas B.A., 1994. Regulation of pea cytosolic ascorbate peroxidase and other antioxidant enzymes during the progression of drought stress and following recovery from drought. Plant J., 5, 397-405. DOI: 10.1111/j.1365-313X.1994.00397.x.

Moller I.M., 2001. PLANT MITOCHONDRIA AND OXIDATIVE STRESS: Electron transport, NADPH turnover, and metabolism of reactive oxygen species. Annu. Rev. Plant Physiol. Plant Mol. Biol., 52, 561-591. DOI: 10.1146/annurev.arplant.52.1.561.

Moller I.M., Jensen P.E., Hansson A., 2007. Oxidative modifications to cellular components in plants. Annu. Rev. Plant Biol., 58, 459-481. DOI: 10.1146/annurev.arplant.58.032806.103946.

Moran J.F., Becana M., Iturbe-Ormaetxe I., Frechilla S., Klucas R.V., Aparicio Tejo P., 1994. Drought induces oxidative stress in pea plants. Planta, 194, 346-352. DOI: 10.1007/BF00197534. 


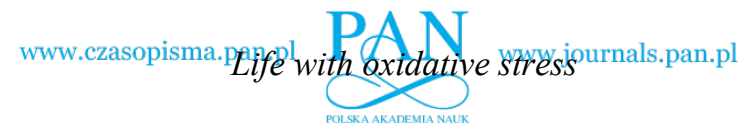

Mullineaux P.M., Rausch T., 2005. Glutathione, photosynthesis and the redox regulation of stress-responsive gene expression. Photosynth. Res., 86, 459-474. DOI: 10.1007/s11120-005-8811-8.

Mur L.A., Kenton P., Lloyd A.J., Ougham H., Prats E., 2008. The hypersensitive response; the centenary is upon us but how much do we know? J. Exp. Bot., 59, 501-520. DOI: 10.1093/jxb/erm239.

Murphy T.M., Huerta A.J., 1990. Hydrogen peroxide formation in cultured rose cells in response to UV-C radiation. Physiol. Plant, 78, 247-253. DOI: 10.1111/j.1399-3054.1990.tb02088.x.

Noctor G., De Paepe R., Foyer C.H., 2007. Mitochondrial redox biology and homeostasis in plants. Trends Plant Sci, 12, 125-134. DOI: 10.1016/j.tplants.2007.01.005.

Noctor G., Gomez L., Vanacker H., Foyer C.H., 2002. Interactions between biosynthesis, compartmentation and transport in the control of glutathione homeostasis and signalling. J. Exp. Bot., 53, 1283-1304. DOI: 10.1093/jexbot/53.372.1283.

Noctor G., Veljovic-Jovanovic S., Foyer C.H., 2000. Peroxide processing in photosynthesis: antioxidant coupling and redox signalling. Phil. Trans. R. Soc. B, 355, 1465-1475. DOI: 10.1098/rstb.2000.0707.

Nunomura A., Hofer T., Moreira P.I., Castellani R.J., Smith M.A., Perry G., 2009. RNA oxidation in Alzheimer disease and related neurodegenerative disorders. Acta Neuropathol., 118, 151-166. DOI: 10.1007/s00401-0090508-1.

Nunomura A., Perry G., Pappolla M.A., Wade R., Hirai K., Chiba S., Smith M.A., 1999. RNA oxidation is a prominent feature of vulnerable neurons in Alzheimer's disease. J. Neurosci., 19, 1959-1964.

O'Kane D., Gill V., Boyd P., Burdon R., 1996. Chilling, oxidative stress and antioxidant responses in Arabidopsis thaliana callus. Planta, 198, 371-377. DOI: 10.1007/BF00620053.

Okuda T., Matsuda Y., Yamanaka A., Sagisaka S., 1991. Abrupt increase in the level of hydrogen peroxide in leaves of winter wheat is caused by cold treatment. Plant Physiol., 97, 1265-1267. DOI: 10.1104/pp.97.3.1265.

Olsson M., 1995. Alterations in lipid composition, lipid peroxidation and anti-oxidative protection during senescence in drought stressed plants and non-drought stressed plants of Pisum sativum. Plant Physiol. Bioch., $33,547-553$.

Omran R.G., 1980. Peroxide levels and the activities of catalase, peroxidase, and indoleacetic acid oxidase during and after chilling cucumber seedlings. Plant Physiol., 65, 407-408. DOI: 10.1104/pp.65.2.407.

Orozco-Cardenas M., Ryan C.A., 1999. Hydrogen peroxide is generated systemically in plant leaves by wounding and systemin via the octadecanoid pathway. Proc. Natl. Acad. Sc.i USA, 96, 6553-6557. DOI: 10.1073/pnas.96.11.6553.

Pastore D., Laus M.N., Di Fonzo N., Passarella S., 2002. Reactive oxygen species inhibit the succinate oxidationsupported generation of membrane potential in wheat mitochondria. FEBS Lett, 516, 15-19. DOI: 10.1016/S0014-5793(02)02454-7.

Prasad T.K., Anderson M.D., Martin B.A., Stewart C.R., 1994. Evidence for chilling-induced oxidative stress in maize seedlings and a regulatory role for hydrogen peroxide. Plant Cell, 6, 65-74. DOI: 10.1105/tpc.6.1.65.

Prasad T.K., Anderson M.D., Stewart C.R., 1995. Localization and characterization of peroxidases in the mitochondria of chilling-acclimated maize seedlings. Plant Physiol., 108, 1597-1605. DOI: 10.1104/pp.108.4.1597.

Pucciariello C., Banti V., Perata P., 2012. ROS signaling as common element in low oxygen and heat stresses. Plant Physiol. Biochem., 59, 3-10. DOI: 10.1016/j.plaphy.2012.02.016.

Puntarulo S., Sanchez R.A., Boveris A., 1988. Hydrogen peroxide metabolism in soybean embryonic axes at the onset of germination. Plant Physiol., 86, 626-630. DOI: 10.1104/pp.86.2.626.

Quan L.J., Zhang B., Shi W.W., Li H.Y., 2008. Hydrogen peroxide in plants: a versatile molecule of the reactive oxygen species network. J. Integr. Plant Biol., 50, 2-18. DOI: 10.1111/j.1744-7909.2007.00599.x.

Raghavendra A.S., Padmasree K., 2003. Beneficial interactions of mitochondrial metabolism with photosynthetic carbon assimilation. Trends Plant Sci., 8, 546-553. DOI: 10.1016/j.tplants.2003.09.015.

Rasmusson A.G., Soole K.L., Elthon T.E., 2004. Alternative NAD(P)H dehydrogenases of plant mitochondria. Annu. Rev. Plant Biol., 55, 23-39. DOI: 10.1146/annurev.arplant.55.031903.141720.

Ren D.T., Yang H.P., Zhang S.Q., 2002. Cell death mediated by MAPK is associated with hydrogen peroxide production in Arabidopsis. J. Biol. Chem., 277, 559-565. DOI: 10.1074/jbc.M109495200.

Rhoads D.M., Umbach A.L., Subbaiah C.C., Siedow J.N., 2006. Mitochondrial reactive oxygen species. Contribution to oxidative stress and interorganellar signaling. Plant Physiol., 141, 357-366. DOI: 10.1104/pp.106.079129. 
Rice-Evans C.A., Sampson J., Bramley P.M., Holloway D.E., 1997. Why do we expect carotenoids to be antioxidants in vivo? Free Radic. Res., 26, 381-398. DOI: 10.3109/10715769709097818.

Richards K.D., Schott E.J., Sharma Y.K., Davis K.R., Gardner R.C., 1998. Aluminum induces oxidative stress genes in Arabidopsis thaliana. Plant Physiol., 116, 409-418. DOI: 10.1104/pp.116.1.409.

del Rio L.A., Palma J.M., Sandalio L.M., Corpas F.J., Pastori G.M., Bueno P., Lopez-Huertas E., 1996. Peroxisomes as a source of superoxide and hydrogen peroxide in stressed plants. Biochem. Soc. Trans., 24, 434438. DOI: $10.1042 / \mathrm{bst} 0240434$.

del Rio L.A., Sandalio L.M., Corpas F.J., Lopez-Huertas E., Palma J.M., Pastori G.M., 1998. Activated oxygenmediated metabolic functions of leaf peroxisomes. Physiol. Plant, 104, 673-680. DOI: 10.1034/j.13993054.1998.1040422.x

del Rio L.A., Sandalio L.M., Palma J.M., BuenoP., Corpas F.J., 1992. Metabolism of oxygen radicals in peroxisomes and cellular implications. Free Radic. Biol. Med., 13, 557-580. DOI: 10.1016/08915849(92)90150-F.

Romero-Puertas M.C., Corpas F.J., Sandalio L.M., Leterrier M., Rodriguez-Serrano M., del Rio L.A., Palma J.M., 2006. Glutathione reductase from pea leaves: response to abiotic stress and characterization of the peroxisomal isozyme. New Phytol., 170, 43-52. DOI: 10.1111/j.1469-8137.2005.01643.x.

Romero D.M., Rios de Molina M.C., Juarez A.B., 2011. Oxidative stress induced by a commercial glyphosate formulation in a tolerant strain of Chlorella kessleri. Ecotoxicol Environ. Saf., 74, 741-747. DOI: 10.1016/j.ecoenv.2010.10.034.

Ros Barcelo A., 1997. Lignification in plant cell walls. Int. Rev. Cytol., 176, 87-132. DOI: 10.1016/S00747696(08)61609-5.

Roxas V.P., Lodhi S.A., Garrett D.K., Mahan J.R., Allen R.D., 2000. Stress tolerance in transgenic tobacco seedlings that overexpress glutathione S-transferase/glutathione peroxidase. Plant Cell Physiol., 41, 1229-1234. DOI: $10.1093 / \mathrm{pcp} / \mathrm{pcd} 051$.

Sandalio L.M., Fernandez V.M., Ruperez F.L., del Rio L.A., 1988. Superoxide free radicals are produced in glyoxysomes. Plant Physiol., 87, 1-4. DOI: 10.1104/pp.87.1.1.

Sandmann G., Boger P., 1980. Copper-mediated lipid peroxidation processes in photosynthetic membranes. Plant Physiol., 66, 797-800. DOI: 10.1104/pp.66.5.797.

De Santis A., Landi P., Genchi G., 1999. Changes of mitochondrial properties in maize seedlings associated with selection for germination at low temperature. Fatty acid composition, cytochrome $c$ oxidase, and adenine nucleotide translocase activities. Plant Physiol., 119, 743-754. DOI: 10.1104/pp.119.2.743.

Scarpeci T.E., Zanor M. I., Carrillo N., Mueller-Roeber B., Valle E.M., 2008. Generation of superoxide anion in chloroplasts of Arabidopsis thaliana during active photosynthesis: a focus on rapidly induced genes. Plant Mol. Biol., 66, 361-378. DOI: 10.1007/s11103-007-9274-4.

Schonbrunn E., Eschenburg S., Shuttleworth W.A., Schloss J.V., Amrhein N., Evans J.N.S., Kabsch W., 2001. Interaction of the herbicide glyphosate with its target enzyme 5-enolpyvuvylshikimate 3-phosphate synthase in atomic detail. Proc. Natl. Acad. Sci. USA, 98, 1376-1380. DOI: 10.1073/pnas.98.4.1376.

Schopfer P., 1994. Histochemical demonstration and localization of $\mathrm{H}_{2} \mathrm{O}_{2}$ in organs of higher-plants by tissue printing on nitrocellulose paper. Plant Physiol, 104, 1269-1275. DOI: 10.1104/pp.104.4.1269.

Schulze-Osthoff K., Bauer M.K., Vogt M., Wesselborg S., 1997. Oxidative stress and signal transduction. Int. J. Vitam. Nutr. Res., 67, 336-342.

Schwanz P., Picon C., Vivin P., Dreyer E., Guehl J.M., Polle A., 1996. Responses of antioxidative systems to drought stress in pendunculate oak and maritime pine as modulated by elevated $\mathrm{CO}_{2}$. Plant Physiol., 110, 393402. DOI:10.1104/pp.110.2.393.

Seifried H.E., Anderson D.E., Fisher E.I., Milner J.A., 2007. A review of the interaction among dietary antioxidants and reactive oxygen species. J. Nutr. Biochem., 18, 567-579. DOI: 10.1016/j.jnutbio.2006.10.007.

Sergiev I.G., Alexieva V.S., Ivanov S.V., Moskova I.I., Karanov E.N., 2006. The phenylurea cytokinin 4 PU-30 protects maize plants against glyphosate action. Pestic. Biochem. Phys., 85, 139-146. DOI: 10.1016/j.pestbp.2006.01.001.

Sgherri C.L.M., Pinzino C., NavariIzzo F., 1996. Sunflower seedlings subjected to increasing stress by water deficit: Changes in $\mathrm{O}_{2}^{-}$production related to the composition of thylakoid membranes. Physiol. Plant, 96, 446452. DOI: 10.1111/j.1399-3054.1996.tb00457.x.

Shan X., Lin C.L., 2006. Quantification of oxidized RNAs in Alzheimer's disease. Neurobiol. Aging., 27, 657662. DOI: 10.1016/j.neurobiolaging.2005.03.022. 
Shan X., Tashiro H., Lin C.L., 2003. The identification and characterization of oxidized RNAs in Alzheimer's disease. J. Neurosci., 23, 4913-4921. DOI:10.2144/000113801.

Sies H., 1991. Oxidative stress: from basic research to clinical application. Am. J. Med., 91, 31S-38S. DOI: 10.1016/0002-9343(91)90281-2.

Sigler K., Chaloupka J., Brozmanova J., Stadler N., Hofer M., 1999. Oxidative stress in microorganisms - I. Microbial vs. higher cells- damage and defenses in relation to cell aging and death. Folia Microbiol (Praha), 44, 587-624.

Smirnoff N., 1993. The role of active oxygen in the response of plants to water deficit and desiccation. New Phytol., 125, 27-58. DOI: 10.1111/j.1469-8137.1993.tb03863.x.

Smirnoff N., 1998. Plant resistance to environmental stress. Curr. Opin. Biotechno.l, 9, 214-219. DOI: 10.1016/S0958-1669(98)80118-3.

Smirnoff N., 2000. Ascorbic acid: metabolism and functions of a multi-facetted molecule. Curr. Opin. Plant Biol., 3, 229-235.

Stieger P.A., Feller U., 1997. Degradation of stromal proteins in pea (Pisum sativum L.) chloroplasts under oxidising conditions. J. Plant Physiol., 151, 556-562. DOI: 10.1016/S0176-1617(97)80230-1.

Strid A., 1993. Alteration in expression of defense genes in Pisum sativum after exposure to supplementary ultraviolet-B radiation. Plant Cell Physiol., 34, 949-953.

Sweetlove L.J., Foyer C.H. , 2004. Roles for reactive oxygen species and antioxidants in plant mitochondria. Kluwer Academic Press, Dordrecht, The Netherlands.

Takahashi M., Asada K., 1988. Superoxide production in aprotic interior of chloroplast thylakoids. Arch. Biochem. Biophys., 267, 714-722. DOI: 10.1016/0003-9861(88)90080-X.

Takahashi N., Kozai D., Kobayashi R., Ebert M., Mori Y., 2011. Roles of TRPM2 in oxidative stress. Cell Calcium, 50, 279-287. DOI: 10.1016/j.ceca.2011.04.006.

Temple M.D., Perrone G.G., Dawes I.W., 2005. Complex cellular responses to reactive oxygen species. Trends Cell Biol., 15, 319-326. DOI: 10.1016/j.tcb.2005.04.003.

Tsang E.W., Bowler C., Herouart D., Van Camp W., Villarroel R., Genetello C., Van Montagu M., Inze D., 1991. Differential regulation of superoxide dismutases in plants exposed to environmental stress. Plant Cell, 3, 783792. DOI: $10.1105 /$ tpc.3.8.783.

Turrens J.F., 2003. Mitochondrial formation of reactive oxygen species. J. Physiol., 552, 335-344. DOI: 10.1113/jphysiol.2003.049478.

Tuteja N., Singh M.B., Misra M.K., Bhalla P.L., Tuteja R., 2001. Molecular mechanisms of DNA damage and repair: progress in plants. Crit. Rev. Biochem. Mol. Biol., 36, 337-397. DOI: 10.1080/20014091074219.

Uotila M., Gullner G., Komives T., 1995. Induction of glutathione S-transferase activity and glutathione level in plants exposed to glyphosate. Physiol. Plant, 93, 689-694. DOI: 10.1111/j.1399-3054.1995.tb05118.x.

Valko M., Leibfritz D., Moncol J., Cronin M.T., Mazur M., Telser J., 2007. Free radicals and antioxidants in normal physiological functions and human disease. Int. J. Biochem. Cell Biol., 39, 44-84. DOI: 10.1016/j.biocel.2006.07.001.

Valko M., Rhodes C.J., Moncol J., Izakovic M., Mazur M., 2006. Free radicals, metals and antioxidants in oxidative stress-induced cancer. Chem. Biol. Interact., 160, 1-40. DOI: 10.1016/j.cbi.2005.12.009.

Verbruggen N., Hermans C., 2008. Proline accumulation in plants: a review. Amino Acids, 35, 753-759. DOI: 10.1007/s00726-008-0061-6.

De Vos C.H., Vonk M.J., Vooijs R., Schat H., 1992. Glutathione depletion due to copper-induced phytochelatin synthesis causes oxidative stress in Silene cucubalus. Plant Physiol., 98, 853-858. DOI: 10.1104/pp.98.3.853.

Vurusaner B., Poli G., Basaga H., 2012. Tumor suppressor genes and ROS: complex networks of interactions. Free Radic. Biol. Med., 52, 7-18. DOI: 10.1016/j.freeradbiomed.2011.09.035.

Watanabe T., Sakai S., 1998. Effects of active oxygen species and methyl jasmonate on expression of the gene for a wound-inducible 1-aminocyclopropane-1-carboxylate synthase in winter squash (Cucurbita maxima). Planta, 206, 570-576. DOI: $10.1007 / \mathrm{s} 004250050434$.

Weckx J.E.J., Clijsters H.M.M., 1996. Oxidative damage and defense mechanisms in primary leaves of Phaseolus vulgaris as a result of root assimilation of toxic amounts of copper. Physio.l Plant, 96, 506-512. DOI: 10.1111/j.1399-3054.1996.tb00465.x.

Weckx J.E.J., Clijsters H.M.M., 1997. Zn phytotoxicity induces oxidative stress in primary leaves of Phaseolus vulgaris. Plant Physiol. Biochem., 35, 405-410. 
White E., Shannon J.S., Patterson R.E., 1997. Relationship between vitamin and calcium supplement use and colon cancer. Cancer Epidemiol. Biomarkers Prev., 6, 769-774.

Willekens H., Van Camp W., Van Montagu M., Inze D., Langebartels C., Sandermann H., 1994. Ozone, sulfur dioxide, and ultraviolet $\mathrm{B}$ have similar effects on mRNA accumulation of antioxidant genes in Nicotiana plumbaginifolia L. Plant Physiol., 106, 1007-1014. DOI: 10.1104/pp.106.3.1007.

Wiseman H., Halliwell B., 1996. Damage to DNA by reactive oxygen and nitrogen species: role in inflammatory disease and progression to cancer. Biochem. J., 313, 17-29.

Zawia N.H., Lahiri D.K., Cardozo-Pelaez F., 2009. Epigenetics, oxidative stress, and Alzheimer disease. Free Radic. Biol. Med., 46, 1241-1249. DOI: 10.1016/j.freeradbiomed.2009.02.006.

Zhu D.H., Scandalios J.G., 1994. Differential accumulation of manganese-superoxide dismutase transcripts in maize in response to abscisic acid and high osmoticum. Plant Physiol., 106, 173-178. DOI: 10.1104/pp.106.1.173. 